\title{
Analisis Stabilitas Lereng Dengan Perkuatan Geotekstil Woven Akibat Pengaruh Termal Menggunakan Metode Elemen Hingga
}

\author{
IMRON MAULANA FAUZI, INDRA NOER HAMDHAN \\ Jurusan Teknik Sipil, Institut Teknologi Nasional, Bandung \\ Email: imronmaulanaf@gmail.com
}

\begin{abstract}
ABSTRAK
Ada beberapa jenis perkuatan tanah untuk mengantisipasi longsoran yang sering digunakan di Indonesia seperti halnya geotekstil. Analisis stabilitas dilakukan pada lereng timbunan dengan kemiringan $1 \mathrm{~V}: 1 \mathrm{H}, 1 \mathrm{~V}: 1,5 \mathrm{H}$ dan $1 \mathrm{~V}: 2 \mathrm{H}$ dengan membandingkan kondisi lereng timbunan tanpa perkuatan geotekstil, lereng timbunan dengan perkuatan geotekstil serta lereng timbunan dengan perkuatan geotekstil yang dipengaruhi oleh termal menggunakan software PLAXIS 2D 2017. Analisis pengaruh termal dilakukan dengan memvariasikan besaran nilai suhu dan parameter termal tanah (kapasitas, konduktivitas dan ekspansi). Terjadi penurunan stabilitas lereng timbunan dengan perkuatan geotekstil yang diakibatkan oleh semakin besarnya nilai suhu termal dan terjadi peningkatan stabilitas lereng dengan perkuatan geotekstil akibat meningkatnya nilai ekspansi termal, sedangkan nilai konduktivitas dan kapasitas termal tidak berpengaruh.
\end{abstract}

Kata kunci: lereng timbunan, geotekstil, stabilitas, suhu, parameter termal tanah.

\begin{abstract}
There are several types of soil reinforcement to anticipate landslide that are often used in Indonesia as well as geotextile. The stability analysis is carried out on the slope of the embankment with a slope of $1 \mathrm{~V}: 1 \mathrm{H}, 1 \mathrm{~V}: 1,5 \mathrm{H}$ and $1 \mathrm{~V}: 2 \mathrm{H}$ by comparing the slope conditions of the embankment without geotextile reinforcement, slope of embankment with geotextile reinforcement and slope of embankment with geotextile reinforcement that influenced by thermal using PLAXIS 2D 2017. The thermal effect analysis is carried out by varying the value of temperature and soil thermal parameters (capacity, conductivity and expansion). There is a decrease in the stability of the embankment slopes with geotextile reinforcement caused by the increasing thermal temperature value and an increase in slope stability with geotextile reinforcement due to the increase of thermal expansion value, while the conductivity and thermal capacity have no effect.
\end{abstract}

Keywords: embankment slope, geotextile, stability, temperature, thermal soil parameter. 


\section{PENDAHULUAN}

\subsection{Latar Belakang}

Indonesia merupakan negara yang beriklim tropis yang hanya memiliki dua musim yaitu musim kemarau dan musim hujan. Selain curah hujan yang tinggi pada musim penghujan, Indonesia juga mendapatkan sinar matahari sepanjang tahun dan memiliki temperatur yang tinggi di saat musim kemarau. Karakteristik iklim seperti itu dapat berdampak terhadap kestabilan struktur tanah yang ada misalnya lereng. Lereng yang tidak stabil sangatlah berbahaya terhadap lingkungan sekitarnya. Iklim merupakan faktor yang seringkali menyebabkan longsoran. Hal tersebut dapat mengurangi kekuatan geser serta daya dukung tanah. Pada umumnya ada beberapa jenis perkuatan tanah untuk mengantisipasi longsoran yang sering digunakan di Indonesia salah satunya yaitu geotekstil karena mempunyai umur rencana yang cukup lama, mendukung beban yang besar dan memiliki fungsi sebagai separator, filter, proteksi, dan perkuatan. Geotekstil merupakan material tekstil berbahan sintetis hasil pabrikasi yang bersifat thermoplastic. Thermoplastic merupakan sifat material yang akan lunak jika dipanaskan dan akan mengeras jika didinginkan.

Kondisi lingkungan seperti cuaca dapat mengurangi kekuatan dari geotekstil yang digunakan sebagai perkuatan lereng. Cuaca yang dimaksud yaitu hujan dan panas. Hujan sering menjadi penyebab yang dominan pada fenomena longsoran dan adanya panas seringkali diabaikan. Geotekstil memiliki sifat thermoplastic, oleh karena itu pengaruh panas (therma) terhadap struktur perlu dipertimbangakan.

Tugas akhir ini menganalisis pengaruh termal terhadap kestabilan lereng yang diperkuat geotekstil untuk mengetahui nilai faktor keamanan lerengnya dengan menerapkan beberapa kondisi thermal yang berbeda dengan menggunakan salah satu fitur semi coupled $\mathrm{TH}-\mathrm{M}$ (Thermo Hydraulic-Mechanical) yang dapat menganalisis pengaruh perubahan suhu pada tegangan dan deformasi tanah secara bersamaan menggunakan metode elemen hingga dimodelkan secara 2D menggunakan software PLAXIS 2D.

\section{KAJIAN PUSTAKA}

\subsection{Lereng}

Lereng yaitu suatu permukaan tanah yang memiliki kemiringan dan membentuk sudut tertentu terhadap bidang horizontal dan tidak terlindungi. Lereng dapat terjadi secara alami maupun sengaja dibuat oleh manusia dengan tujuan tertentu (Bowles, 1984). Menurut SNI 8460 (2017), lereng terbagi menjadi beberapa jenis, diantaranya adalah:

1. Lereng alam

Lereng alam terbentuk akibat kegiatan alam (erosi, gerakan tektonik, dan sebagainya). Material yang membentuk lereng memiliki kecenderungan tergelincir akibat beratnya sendiri dan gaya-gaya luar yang ditahan oleh kuat geser tanah dari material tersebut.

2. Lereng galian

Lereng galian terbentuk akibat kegiatan manusia berupa penggalian atau pemotongan pada tanah asli. Perancangan pemotongan lereng galian yang dimaksud adalah usaha untuk membuat suatu lereng dengan kemiringan tertentu yang cukup aman dan ekonomis.

3. Lereng timbunan (embankment)

Lereng timbunan terbentuk akibat kegiatan manusia berupa penimbunan yang digunakan untuk badan jalan raya, jalan kereta api, dan bendungan tanah. Sifat teknis lereng timbunan dipengaruhi oleh jenis tanah, cara penimbunan dan derajat kepadatan tanah. 


\subsection{Geotekstil}

Geotekstil merupakan suatu bahan sintetis permeable yang bahan dasarnya terbuat dari tekstil polimer seperti polyester atau polypropylene. Geotekstil dapat digunakan atau berfungsi sebagai separator, filter, proteksi, dan perkuatan. Secara umum geotekstil terbagi menjadi dua jenis yaitu geotekstil teranyam (woven) dan geotekstil tak teranyam (non woven). Fungsi geotekstil woven yaitu sebagai bahan stabilisasi tanah dasar (terutama pada tanah dasar lunak), karena mempunyai tensile strength (kuat tarik) yang lebih tinggi dibandingkan dengan geotekstil non woven.

\subsection{Analisis Stabilitas}

Analisis stabilitas lereng adalah menentukan faktor keamanan dari bidang longsor. Faktor keamanan (FK) didefinisikan sebagai nilai perbandingan antara gaya yang menahan dan gaya yang menggerakkan. Faktor keamanan dapat didefinisikan dalam Persamaan 1.

$$
F K=\frac{\tau}{\tau_{d}}
$$

halmana:

$F K=$ faktor keamanan,

$\tau=$ tahanan geser maksimum yang dapat dikerahkan oleh tanah $\left[\mathrm{kN} / \mathrm{m}^{2}\right]$,

$\tau_{d} \quad=$ tegangan geser akibat gaya dorong tanah yang mengakibatkan longsor $\left[\mathrm{kN} / \mathrm{m}^{2}\right]$.

Nilai-nilai faktor keamanan (FK) atau safety factor (SF) untuk menilai kestabilan suatu lereng menurut Bowles (1984) yaitu sebagai berikut:

$$
\begin{array}{ll}
\mathrm{SF}<1,07 & : \text { keruntuhan biasa terjadi (labil) } \\
1,07<\mathrm{SF}<1,25 & : \text { keruntuhan pernah terjadi (kritis) } \\
\mathrm{SF} \geq 1,25 & \text { : keruntuhan jarang terjadi (stabil) }
\end{array}
$$

\subsection{Parameter Tanah}

Parameter tanah pada pemodelan PLAXIS 2D 2017 digunakan untuk menggambarkan kondisi tanah asli yang akan digunakan. Adapun parameter-parameter tanah yang digunakan diantaranya adalah modulus elastisitas $(E)$, poisson ratio $(\mu)$, sudut geser $(\varphi)$ dan kohesi $(c)$.

\subsection{Parameter Termal}

Parameter termal tanah yang digunakan pada penelitian ini diantaranya adalah:

1. Konduktivitas termal (thermal conductivity)

Konduktivitas termal $\left(\lambda_{s}\right)$ pada tanah merupakan salah satu parameter termal yang menunjukkan banyaknya energi yang dapat disalurkan di dalam tanah. Nilai konduktivitas termal dapat dilihat pada Tabel 1. Adapun cara dalam menghitung nilai konduktivitas termal tanah menurut Gonnet et al (2004), yaitu dengan menggunakan Persamaan 2 berikut.

$$
\lambda_{s}=\rho_{s} \times C_{p} \times h
$$

halmana:

$\rho_{s}=$ kerapatan partikel $\left[\mathrm{kg} / \mathrm{m}^{3}\right]$,

$C_{p}=$ kapasitas termal $[\mathrm{J} / \mathrm{Kg} / \mathrm{K}]$,

$h=$ thermal diffusivity $\left[\mathrm{m}^{2} / \mathrm{s}\right]$.

2. Kapasitas termal khusus (spesific heat capacity)

Kapasitas termal khusus $\left(\boldsymbol{C}_{\boldsymbol{s}}\right)$ pada tanah merupakan salah satu parameter termal yang menunjukkan kuantitas dari energi termal (panas) yang dapat disimpan di dalam tanah 
per satuan massa. Nilai kapasitas termal dapat dilihat pada Tabel 1. Adapun persamaan yang dapat digunakan untuk menghitung nilai kapasitas termal tanah menurut Ghuman dan Lal (1985), yaitu ditunjukkan pada Persamaan 3 berikut ini.

$$
C_{v}=0,46 X_{m}+0,6 X_{0}+X_{w}
$$

halmana:

$X_{m}=$ fraksi volume mineral tanah,

$X_{0}=$ fraksi volume organik,

$X_{w}=$ fraksi volume air.

Tabel 1. Nilai Konduktivitas dan Kapasitas Termal Tanah

\begin{tabular}{ccc}
\hline Jenis Tanah & Konduktivitas Termal [W/m/K] & Kapasitas Termal Khusus [J/Kg/K] \\
\hline Kerikil & 4,44 & 1.175 \\
\hline Pasir & $0,15-5,03$ & $800-1.747$ \\
\hline Lempung & $0,25-4,20$ & $800-2.646$ \\
\hline
\end{tabular}

(Sumber: Hamdhan dan Clarke, 2010)

3. Koefisien ekspansi termal (thermal expansion coefficients)

Koefisien ekspansi termal $(\boldsymbol{\alpha})$ merupakan salah satu parameter termal yang menunjukkan besar dari pemuaian yang disebabkan oleh adanya peningkatan suhu. Nilai koefisien ekspansi termal pada mineral tanah lempung dapat dilihat pada Tabel 2. Adapun persamaan yang dapat digunakan untuk menghitung nilai kapasitas termal tanah menurut Agar et al (1986), yaitu pada Persamaan 4 berikut ini.

$$
\alpha_{v}=\frac{\varepsilon_{v}}{\Delta T}
$$

halmana:

$\alpha_{v}=$ ekspansi termal $[1 / K]$,

$\varepsilon_{v}=$ perubahan volume Kumulatif $(\Delta V / V)$,

$\Delta T=$ perbedaan suhu $[\mathrm{K}]$.

Tabel 2. Rata-Rata Koefisien Ekspansi Termal Linear

\begin{tabular}{cccc} 
Mineral & $\begin{array}{c}\text { Perpendicular } \\
\boldsymbol{\alpha}_{\mathbf{1}} \mathbf{1}_{\mathbf{1 0}}^{\mathbf{6}} \mathbf{K}^{\mathbf{- 1}}\end{array}$ & $\begin{array}{c}\text { Parallel } \\
\boldsymbol{\alpha}_{\mathbf{2}} \boldsymbol{1}^{\mathbf{1 0}} \mathbf{K}^{\mathbf{- 1}}\end{array}$ & $\begin{array}{c}\text { Temp. Range } \\
{\left[{ }^{\mathbf{}} \mathbf{C}\right]}\end{array}$ \\
\hline Muscovite & $17,8 \pm 0,59$ & $3,5 \pm 1,3$ & $25-600$ \\
\hline Phlogopite & $17,8 \pm 1,40$ & $14 \pm 3,0$ & $25-350$ \\
\hline Kaolinite & $18,6 \pm 1,30$ & $5,2 \pm 1,7$ & $25-400$ \\
\hline Dickite & $14,9 \pm 0,84$ & $5,9 \pm 0,4$ & $25-500$ \\
\hline Halloysite & $10,0 \pm 1,50$ & $6,0 \pm 2,0$ & $25-350$ \\
\hline Serpentine & $10,2 \pm 0,90$ & $6,9 \pm 1,7$ & $25-500$ \\
\hline Pyrophylite & $14,9 \pm 1,80$ & $12,2 \pm 0,7$ & $25-400$ \\
\hline Talc & $16,3 \pm 2,40$ & $3,7 \pm 1,4$ & $25-700$ \\
\hline Chlorite & $9,0 \pm 2,30$ & $11,1 \pm 1,4$ & $25-500$
\end{tabular}

(Sumber: Jobmann et al, 2017)

4. Kerapatan partikel tanah (particle density)

Kerapatan partikel tanah merupakan berat partikel tanah individu per satuan volume. Menurut Smith dan Smith (1998) besaran nilai kerapatan partikel $\left(\boldsymbol{\rho}_{\boldsymbol{s}}\right)$ bisa didapatkan dari nilai specific gravity $\left(\boldsymbol{G}_{\boldsymbol{s}}\right)$ dengan menggunakan Persamaan $\mathbf{7}$ yang merupakan penurunan dari Persamaan 5 dan Persamaan 6. 


$$
\begin{gathered}
\rho_{s}=\frac{M_{s}}{V_{s}} \\
G_{s}=\frac{\rho_{s}}{\rho_{w}} \\
\rho_{s}=G_{s} \times \rho_{w}
\end{gathered}
$$

halmana:

$\rho_{s}=$ kerapatan partikel tanah $\left[\mathrm{t} / \mathrm{m}^{3}\right]$,

$G_{S}=$ berat jenis (specific gravity),

$\rho_{w}=$ kerapatan air $\left(\rho_{w}=1 \mathrm{t} / \mathrm{m}^{3}\right)$.

Adapun nilai specific gravity $\left(G_{s}\right)$ dapat dilihat pada Tabel 3.

Tabel 3. Berat Jenis Tanah $\left(G_{s}\right)$

\begin{tabular}{cc}
\hline Jenis Tanah & Berat Jenis \\
\hline Kerikil & $2,65-2,68$ \\
Pasir & $2,65-2,68$ \\
Lanau tak organik & $2,62-2,68$ \\
Lempung organik & $2,58-2,65$ \\
Lempung tak organik & $2,68-2,75$ \\
Humus & 1,37 \\
Gambut & $1,25-1,80$ \\
\hline
\end{tabular}

(Sumber: Hardiyatmo, 2002)

\subsection{Aplikasi PLAXIS 2D 2017}

PLAXIS 2D merupakan software berbasis metode elemen hingga dalam pemodelan dua dimensi yang digunakan dalam menganalisis deformasi, stabilitas dan aliran air tanah dalam bidang geoteknik maupun mekanika batuan. Pemodelan lereng pada software PLAXIS menggunakan bentuk pemodelan plane strain. Model plane strain merupakan bentuk pemodelan yang digunakan untuk menganalisis struktur dengan potongan melintang geometri yang relatif seragam. Bentuk pemodelan plane strain dapat dilihat pada Gambar $\mathbf{1}$.

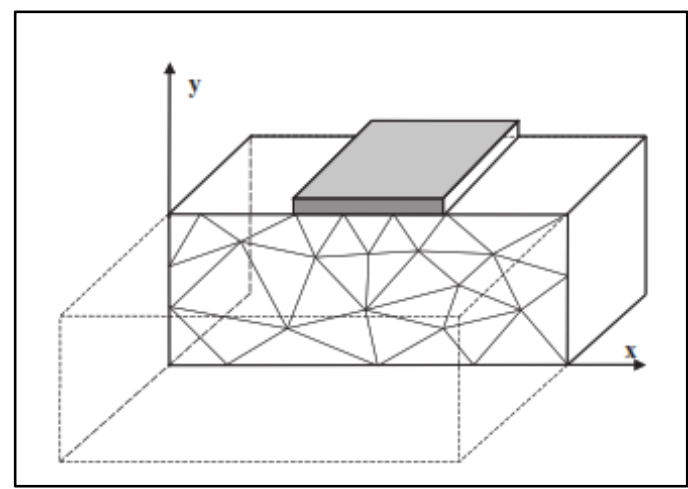

Gambar 1. Bentuk Plane Strain (Sumber: Brinkgreve et al, 2016)

\subsection{Model Material}

Model material yang digunakan yaitu model Mohr-Coulomb. Mohr-Coulomb yaitu pemodelan tanah yang paling umum digunakan, perilakunya mengikuti kriteria Mohr-Coulomb. Teori Mohr menguraikan bahwa kondisi keruntuhan suatu bahan terjadi oleh akibat adanya kombinasi keadaan kritis dari tegangan normal dan tegangan geser (Das, 1991). Hubungan antara tegangan normal dan tegangan geser pada sebuah bidang keruntuhan dinyatakan menurut Persamaan 8 dan Persamaan 9. 


$$
\begin{gathered}
\tau=f(\sigma) \\
\tau_{f}=c+\sigma \tan \varphi
\end{gathered}
$$

halmana:

$$
\begin{array}{ll}
\tau & =\text { tegangan geser }\left[\mathrm{kN} / \mathrm{m}^{2}\right], \\
\mathrm{c} & =\text { kohesi }\left[\mathrm{kN} / \mathrm{m}^{2}\right], \\
\sigma & =\text { tegangan normal }\left[\mathrm{kN} / \mathrm{m}^{2}\right],
\end{array}
$$

$\tan \varphi=$ koefisien geser dalam batuan .

\section{METODE PENELITIAN}

Tugas akhir membahas mengenai pengaruh termal terhadap stabilitas lereng yang diperkuat geotekstil. Secara umum prosedur analisis yang dilakukan dalam penelitian ini seperti yang ditunjukkan pada Gambar 2.

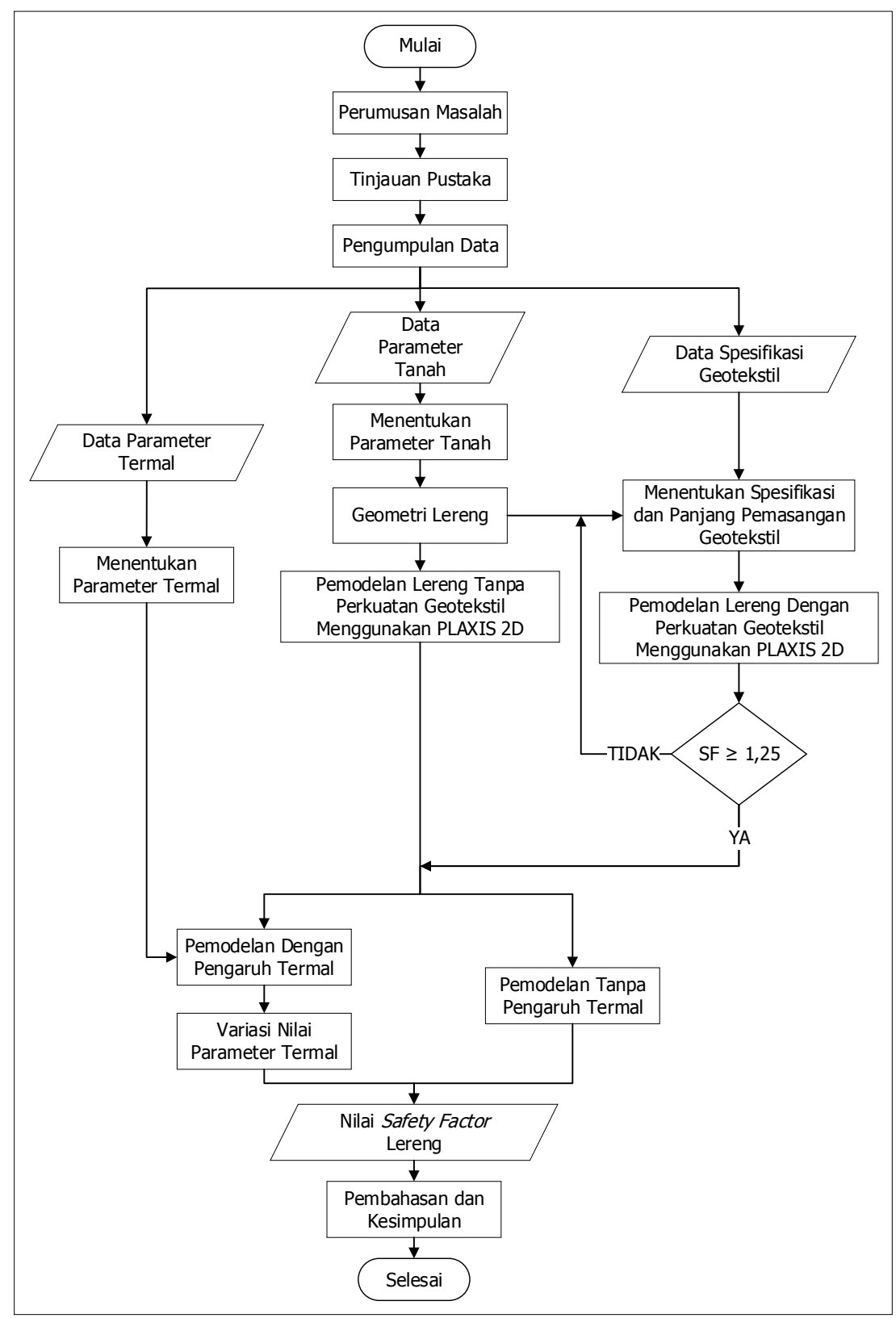

Gambar 2. Bagan alir penelitian

RekaRacana: Jurnal Teknik Sipil - 66 


\section{HASIL PENELITIAN DAN PEMBAHASAN}

\subsection{Analisis Pemodelan}

Analisis stabilitas lereng timbunan dimodelkan dengan satu jenis tanah lempung homogen dengan parameter tanah seperti pada Tabel 4. Analisis stabilitas lereng timbunan ini dilakukan dengan menggunakan software PLAXIS 2D yang berbasis elemen hingga. Hasil analisis stabilitas lereng timbunan yang didapatkan adalah nilai faktor keamanan dan letak bidang longsor yang akan dibandingkan antar kondisinya. Pada penelitian ini pemodelan yang dilakukan terbagi menjadi tiga kondisi yaitu, lereng timbunan tanpa perkuatan geotekstil, lereng timbunan dengan perkuatan geotekstil serta lereng timbunan dengan perkuatan geotekstil yang dipengaruhi oleh termal. Ketiga kondisi pada pemodelan tersebut akan diterapkan pada lereng timbunan dengan kemiringan $1 \mathrm{~V}: 1 \mathrm{H}, 1 \mathrm{~V}: 1,5 \mathrm{H}$ dan $1 \mathrm{~V}: 2 \mathrm{H}$. Data parameter geotekstil terdapat pada Tabel 5, sedangkan input data geotekstil dengan kuat tarik sebesar $35 \mathrm{kN} / \mathrm{m}$ pada software PLAXIS 2D terdapat pada Tabel 6.

Tabel 4. Data Parameter Tanah

\begin{tabular}{ccccccccc}
\hline $\begin{array}{c}\text { Jenis } \\
\text { Tanah }\end{array}$ & $\begin{array}{c}\gamma_{\text {unsat }} \\
{\left[\mathbf{k N} / \mathbf{m}^{3}\right]}\end{array}$ & $\begin{array}{c}\gamma_{\text {sat }} \\
{\left[\mathbf{k N} / \mathbf{m}^{3}\right]}\end{array}$ & $\begin{array}{c}E \\
{\left[\mathbf{k N} / \mathbf{m}^{2}\right]}\end{array}$ & $\boldsymbol{v}$ & $\begin{array}{c}\boldsymbol{C} \\
{\left[\mathbf{k N} / \mathbf{m}^{2}\right]}\end{array}$ & $\begin{array}{c}\varphi \\
{\left[{ }^{\circ}\right]}\end{array}$ & $\begin{array}{c}\boldsymbol{\psi} \\
{\left[{ }^{\circ}\right]}\end{array}$ & $\begin{array}{c}K_{x}, K_{y} \\
{[\mathbf{m} / \mathbf{d a y}]}\end{array}$ \\
\hline Lempung & 16 & 18 & 10.000 & 0,15 & 27 & 6 & 0 & 0,001 \\
\hline
\end{tabular}

Tabel 5. Data Parameter Geotekstil

\begin{tabular}{cccc}
\hline $\begin{array}{c}\text { Kemiringan } \\
\text { Lereng }\end{array}$ & $\begin{array}{c}\text { Tipe } \\
\text { Geoteksil }\end{array}$ & $\begin{array}{c}\text { Kuat Tarik } \\
{[\mathbf{k N} / \mathbf{m}]}\end{array}$ & $\begin{array}{c}\text { Elongasi } \\
{[\%]}\end{array}$ \\
\hline $1 \mathrm{~V}: 1 \mathrm{H}$ & GWF $30-165$ & 35 & 25 \\
\hline $1 \mathrm{~V}: 1,5 \mathrm{H}$ & GWF 30-165 & 35 & 25 \\
\hline $1 \mathrm{~V}: 2 \mathrm{H}$ & GWF 30-165 & 35 & 25 \\
\hline
\end{tabular}

Tabel 6. Data Parameter Geotekstil pada Software PLAXIS 2D

\begin{tabular}{ccc} 
Material Type & $\boldsymbol{E} \boldsymbol{A}$ & $\mathbf{N p}$ \\
\hline Elastoplastic & $140 \mathrm{kN} / \mathrm{m}$ & $28,926 \mathrm{kN} / \mathrm{m}$ \\
\hline
\end{tabular}

\subsection{Pemodelan Lereng Timbunan tanpa Perkuatan dan Pemodelan dengan Menggunakan Perkuatan}

Lereng timbunan dimodelkan tanpa menggunakan perkuatan untuk mengetahui nilai SF awal, sehingga diketahui kondisi lereng dalam keadaan kritis sebelum dipasangi perkuatan. Model lereng timbunan dipasangi geotekstil untuk meningkatkan kestabilan lerengnya hingga menunjukkan kenaikan nilai SF dari kondisi kritis hingga mencapai kondisi lereng yang stabil seperti yang ditunjukkan pada Tabel 7.

Tabel 7. Perbandingan Nilai SF Lereng

\begin{tabular}{ccc}
\hline \multirow{2}{*}{$\begin{array}{c}\text { Kemiringan } \\
\text { Lereng }\end{array}$} & \multicolumn{2}{c}{ SF } \\
\cline { 2 - 3 } & $\begin{array}{c}\text { Tanpa } \\
\text { Perkuatan }\end{array}$ & $\begin{array}{c}\text { Dengan } \\
\text { Perkuatan }\end{array}$ \\
\hline $1 \mathrm{~V}: 1 \mathrm{H}$ & 1,074 & 1,262 \\
\hline $1 \mathrm{~V}: 1,5 \mathrm{H}$ & 1,159 & 1,253 \\
\hline $1 \mathrm{~V}: 2 \mathrm{H}$ & 1,236 & 1,308 \\
\hline
\end{tabular}


Adanya penggunaan geotekstil dapat meningkatkan kestabilan lereng dikarenakan letak bidang longsor yang berpindah akibat penggunaan geotekstil.

\subsection{Pemodelan Lereng Timbunan Menggunakan Perkuatan dengan Pengaruh Termal}

Analisis ini bertujuan untuk mengetahui seberapa besar pengaruh dari suhu, dan nilai dari masing-masing parameter termal terhadap kestabilan lereng. Ada tiga kondisi termal yang dilakukan dalam penelitian ini, diantaranya adalah:

1. Pemodelan Lereng dengan Variasi Suhu Tanah

Kondisi pada pemodelan ini yaitu diterapkan kondisi termal terhadap lereng dengan kemiringan $1 \mathrm{~V}: 1 \mathrm{H}$ tanpa perkuatan geotekstil. Pada pemodelan ini suhu tanah divariasikan dan suhu pada thermal boundary ditetapkan sebesar $32^{\circ} \mathrm{C}$ (suhu maksimum rata-rata di Indonesia) atau setara dengan $305,15 \mathrm{~K}$, sehingga dapat diketahui pengaruh kondisi termal pada tanah dan pengaruh input data suhu tanah terhadap kestabilan lereng. Hasil analisa kondisi termal pada lereng tanpa perkuatan dapat dilihat pada Tabel 8.

\section{Tabel 8. Hasil Analisis Kestabilan Lereng Akibat Variasi Suhu Tanah}

\begin{tabular}{ccc}
$\begin{array}{c}\text { Suhu Tanah } \\
{\left[{ }^{\circ} \mathbf{C}\right]}\end{array}$ & $\begin{array}{c}\text { Suhu Thermal } \\
\text { Boundary }\left[{ }^{\circ} \mathbf{C}\right]\end{array}$ & SF \\
\hline 20 & 32 & 1,076 \\
\hline 25 & & 1,077 \\
\hline 30 & & 1,078 \\
\hline \multicolumn{2}{c}{ Tanpa Termal } & 1,074 \\
\hline
\end{tabular}

Dari hasil analisa menunjukkan tidak adanya pengaruh yang signifikan terhadap kestabilan lereng akibat diterapkannya suhu tanah dan termal, karena software PLAXIS 2D memiliki keterbatasan yaitu tidak dapat memberikan efek suhu terhadap perubahan pada sifat mekanik tanah sehingga tidak ada pengaruh termal terhadap kestabilan lereng timbunan tanpa perkuatan.

2. Pemodelan Lereng dengan Variasi Suhu Termal

Kondisi pada pemodelan ini yaitu diterapkan kondisi termal terhadap lereng timbunan dengan perkuatan geotekstil yang memiliki kemiringan $1 \mathrm{~V}: 1 \mathrm{H}$. Dalam pemodelan ini suhu pada thermal boundary divariasikan. Hasil analisa pemodelan lereng timbunan dengan perkuatan geotekstil akibat variasi suhu pada thermal boundary dapat dilihat pada Gambar 3.

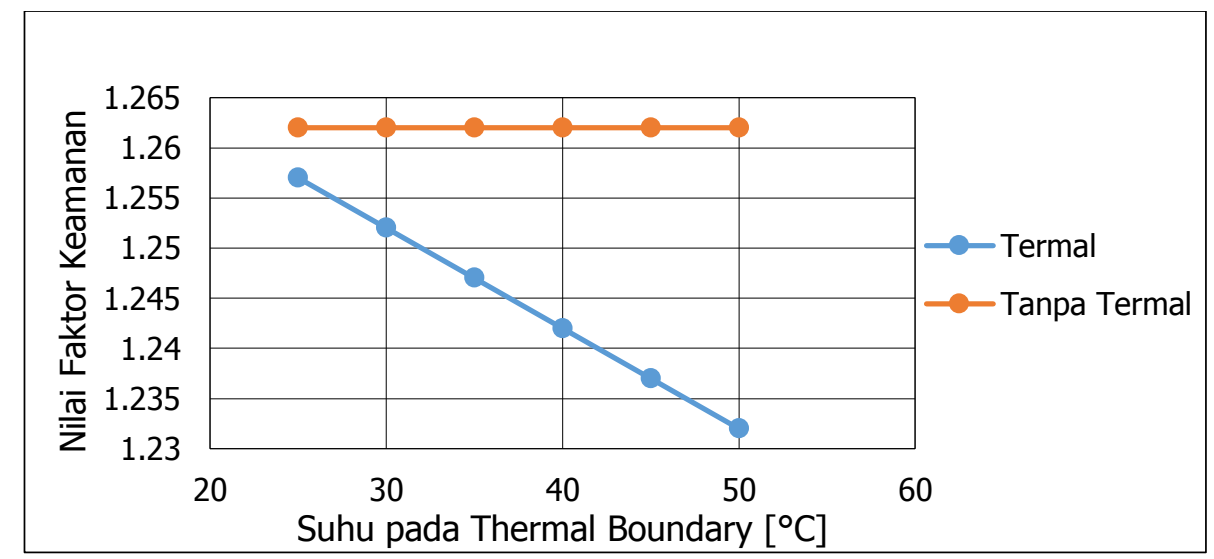

Gambar 3. Grafik pengaruh variasi suhu thermal boundary terhadap kestabilan lereng 
Hasil analisa menunjukan bahwa semakin tinggi suhu pada thermal boundary yang diberikan, maka semakin rendah nilai kestabilan lereng timbunan yang didapatkan, meskipun perubahan nilai kestabilan lereng yang terjadi tidak signifikan. Hal ini terjadi akibat menurunnya nilai kuat tarik geotekstil seiring bertambahnya suhu pada thermal boundary. Nilai $S F$ hasil analisa dapat dilihat pada Tabel 9.

Tabel 9. Pengaruh Variasi Suhu Thermal Boundary Terhadap Kestabilan Lereng

\begin{tabular}{cc} 
Suhu Thermal Flow $\left[{ }^{\circ} \mathbf{C}\right]$ & Nilai Faktor Kemanan $(\boldsymbol{S F})$ \\
\hline Tanpa Termal & 1,262 \\
\hline 25 & 1,257 \\
\hline 30 & 1,252 \\
\hline 35 & 1,247 \\
\hline 40 & 1,242 \\
\hline 45 & 1,237 \\
\hline 50 & 1,232 \\
\hline
\end{tabular}

3. Pemodelan Lereng dengan Variasi Parameter Termal Tanah

Kondisi pada pemodelan ini yaitu diasumsikan suhu thermal boundary sebesar $35^{\circ} \mathrm{C}$ pada ketiga jenis kemiringan, namun masing-masing variasi pemodelan diterapkan nilai parameter termal tanah yang berbeda-beda. Pada pemodelan ini akan dilakukan analisa mengenai pengaruh perubahan parameter termal tanah (konduktivitas, kapasitas dan ekspansi) terhadap kestabilan lereng.

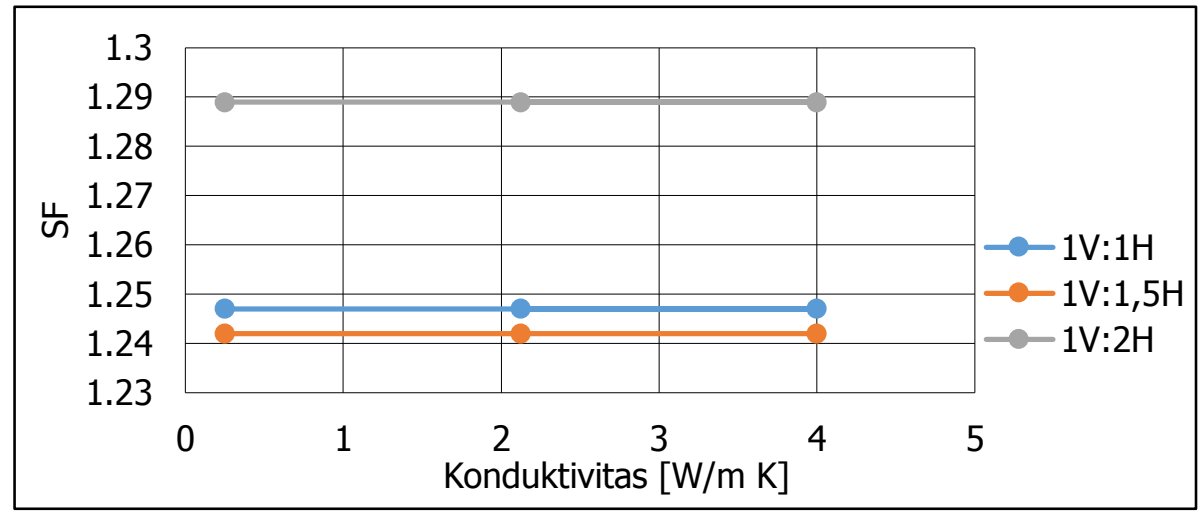

Gambar 4. Grafik pengaruh variasi nilai konduktivitas

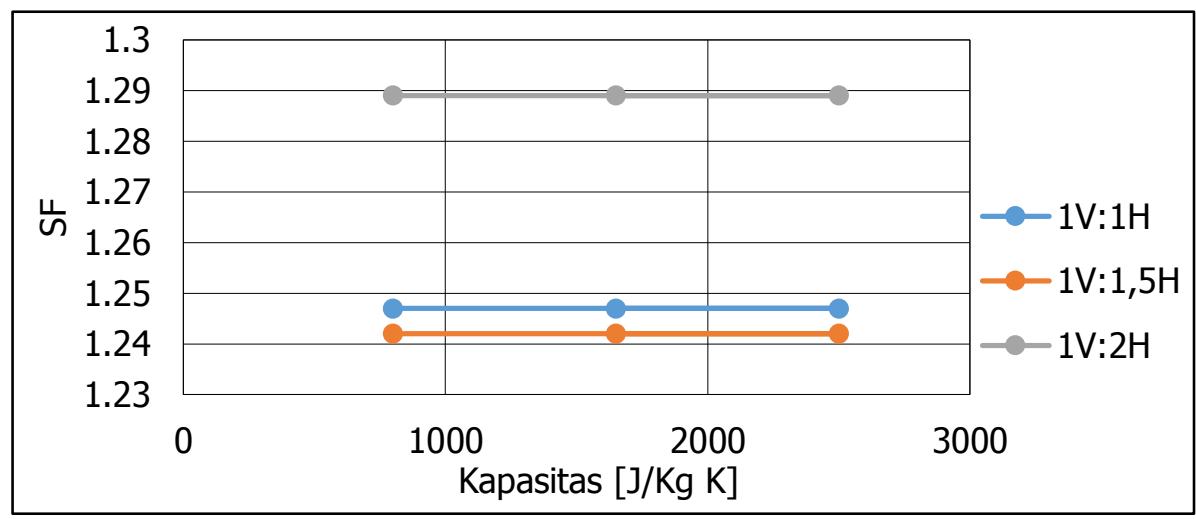

Gambar 5. Grafik pengaruh variasi nilai konduktivitas 
Hasil analisa pada Gambar 4 dan Gambar 5 menunjukkan bahwa perbedaan nilai konduktivitas dan kapasitas termal tidak berpengaruh terhadap kestabilan lereng, dikarenakan kedua nilai tersebut hanya mempengaruhi sifat fisik tanah tanpa mempengaruhi sifat mekaniknya, sehingga kurang berpengaruh terhadap kekuatan tanah. Nilai $S F$ hasil analisa dapat dilihat pada Tabel $\mathbf{1 0}$.

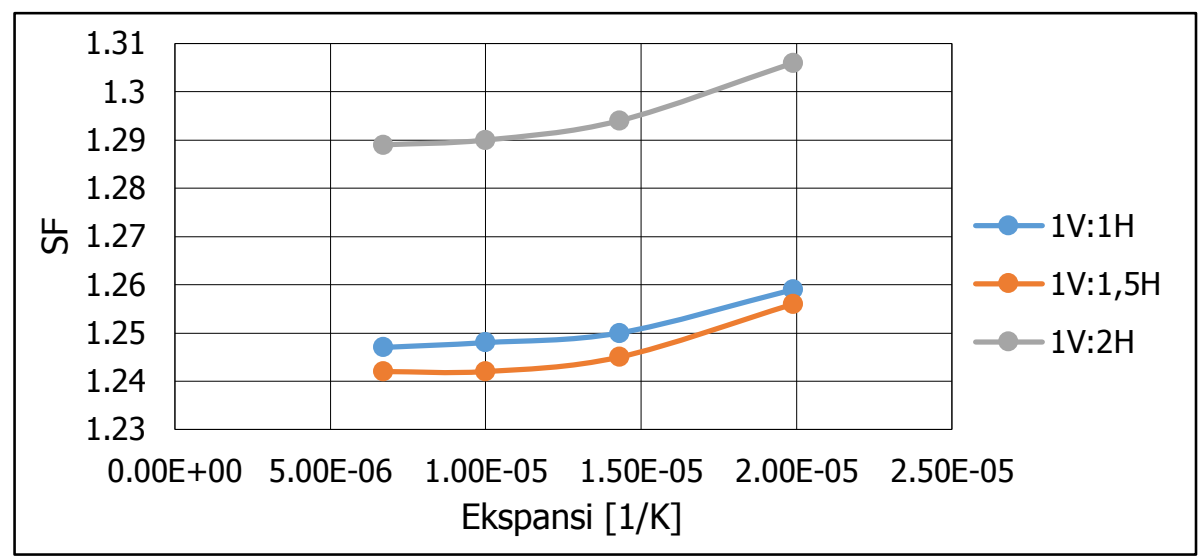

Gambar 6. Grafik pengaruh variasi nilai ekspansi

Hasil analisa pada Gambar 6 menunjukkan bahwa semakin tinggi nilai ekspansi, maka semakin tinggi nilai kestabilan lerengnya. Hal ini disebabkan oleh nilai ekspansi tanah berpengaruh terhadap volumetrik tanah, semakin tinggi nilai ekspansi tanah, maka volume tanah semakin besar, oleh karena itu dengan meningkatnya volumetrik tanah, gesekan yang terjadi antara tanah dengan geotekstil semakin tinggi, sehingga kestabilan tanah dapat meningkat. Nilai $S F$ hasil analisa dapat dilihat pada Tabel $\mathbf{1 0 .}$

Tabel 10. Perbandingan Hasil Analisa

\begin{tabular}{|c|c|c|c|c|c|c|c|}
\hline \multirow{3}{*}{$\begin{array}{c}\text { Variasi } \\
\text { Pemodelan }\end{array}$} & \multicolumn{4}{|c|}{ Parameter Termal } & \multirow{2}{*}{\multicolumn{3}{|c|}{$\begin{array}{c}\text { Nilai Safety Factor }(S F) \text { Lereng } \\
\text { Menggunakan Geotekstil } \\
\text { dengan Pengaruh Termal } \\
{\left[35^{\circ} \mathrm{C}\right]}\end{array}$}} \\
\hline & \multirow{2}{*}{$\begin{array}{c}C_{s} \\
{[\mathrm{~J} / \mathrm{Kg} \mathrm{K}]}\end{array}$} & \multirow{2}{*}{$\begin{array}{c}\lambda_{s} \\
{[W / m k]}\end{array}$} & \multirow{2}{*}{$\begin{array}{c}\alpha \\
{[1 / K]}\end{array}$} & \multirow{2}{*}{$\begin{array}{c}\rho_{s} \\
{\left[t / m^{3}\right]}\end{array}$} & & & \\
\hline & & & & & 1V:1H & $1 \mathrm{~V}: 1,5 \mathrm{H}$ & $1 V: 2 H$ \\
\hline A.1 & \multirow{9}{*}{800} & \multirow{4}{*}{0,25} & $6,7 \times 10-6$ & \multirow{18}{*}{2,72} & 1,247 & 1,242 & 1,289 \\
\hline A.2 & & & $10,0 \times 10-6$ & & 1,248 & 1,242 & 1,290 \\
\hline A.3 & & & $14,3 \times 10-6$ & & 1,250 & 1,245 & 1,294 \\
\hline A.4 & & & $19,9 \times 10-6$ & & 1,259 & 1,256 & 1,306 \\
\hline A. 5 & & 2,125 & $6,7 \times 10-6$ & & 1,247 & 1,242 & 1,289 \\
\hline A.6 & & \multirow{4}{*}{4} & $6,7 \times 10-6$ & & 1,247 & 1,242 & 1,289 \\
\hline A.7 & & & $10,0 \times 10-6$ & & 1,248 & 1,242 & 1,290 \\
\hline A.8 & & & $14,3 \times 10-6$ & & 1,250 & 1,245 & 1,294 \\
\hline A.9 & & & $19,9 \times 10-6$ & & 1,259 & 1,256 & 1,306 \\
\hline $\mathrm{B}$ & 1.650 & 0,25 & $6,7 \times 10-6$ & & 1,247 & 1,242 & 1,289 \\
\hline C.1 & \multirow{8}{*}{2.500} & \multirow{4}{*}{0,25} & $6,7 \times 10-6$ & & 1,247 & 1,242 & 1,289 \\
\hline C. 2 & & & $10,0 \times 10-6$ & & 1,248 & 1,242 & 1,290 \\
\hline C.3 & & & $14,3 \times 10-6$ & & 1,250 & 1,245 & 1,294 \\
\hline C.4 & & & $19,9 \times 10-6$ & & 1,259 & 1,256 & 1,306 \\
\hline C.5 & & \multirow{4}{*}{4} & $6,7 \times 10-6$ & & 1,247 & 1,242 & 1,289 \\
\hline C. 6 & & & $10,0 \times 10-6$ & & 1,248 & 1,242 & 1,290 \\
\hline C.7 & & & $14,3 \times 10-6$ & & 1,250 & 1,245 & 1,294 \\
\hline C.8 & & & $19,9 \times 10-6$ & & 1,259 & 1,256 & 1,306 \\
\hline
\end{tabular}


Perbedaan letak bidang gelincir dari ketiga kondisi pemodelan lereng yang telah dilakukan dapat dilihat pada Gambar 7.

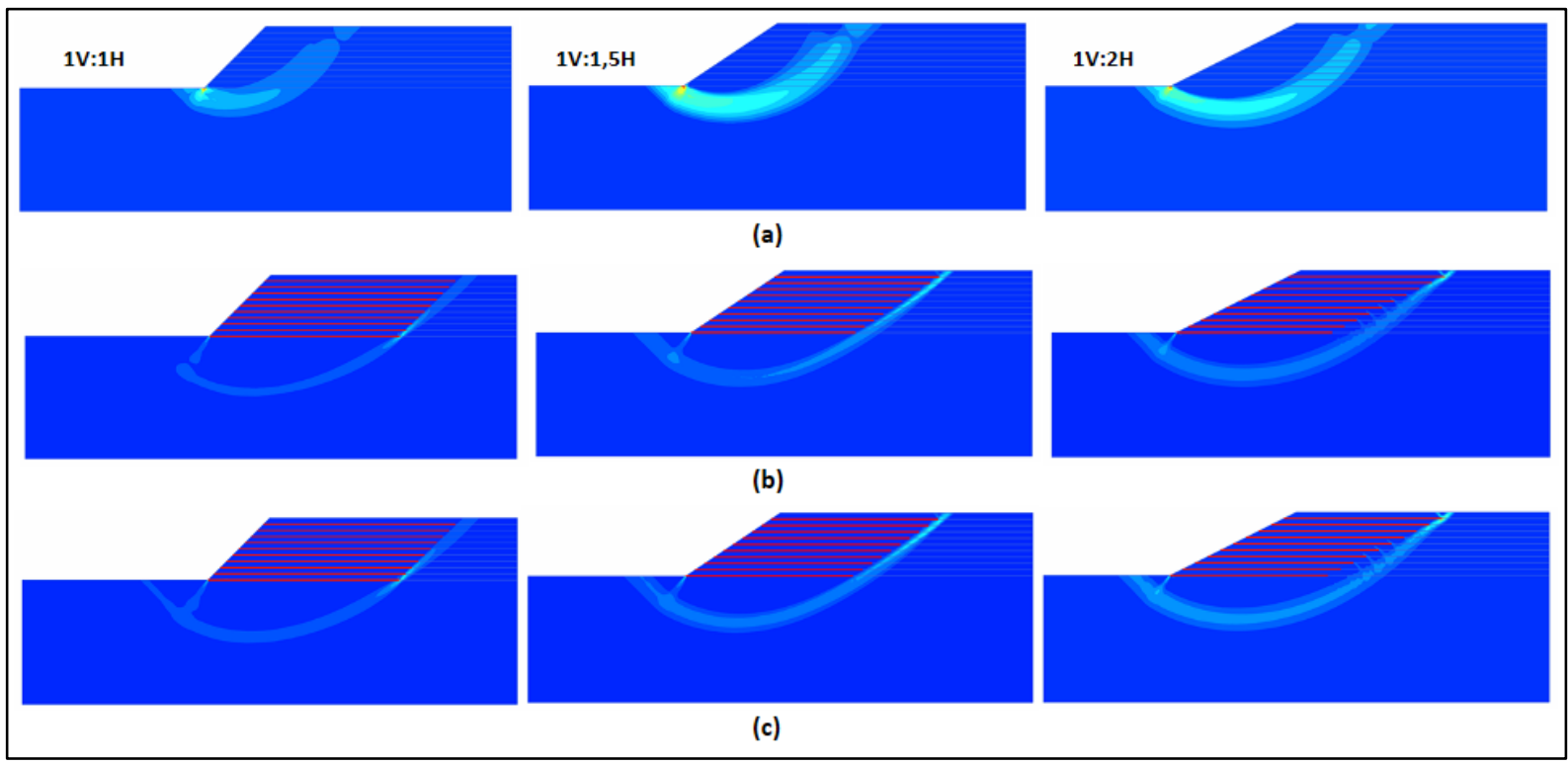

Gambar 7. Bidang gelincir: (a) tanpa perkuatan; (b) menggunakan perkuatan tanpa pengaruh termal; (c) menggunakan perkuatan dengan pengaruh termal

Hasil analisa pada Gambar 7 menunjukkan bahwa penggunaan geotekstil mempengaruhi letak bidang gelincir, namun tidak ada pengaruh termal terhadap letak bidang gelincir.

\section{KESIMPULAN}

Setelah dilakukan analisis stabilitas lereng timbunan yang diperkuat geotekstil pada tiga jenis kemiringan akibat adanya pengaruh termal dengan satu jenis model tanah, yaitu tanah lempung, maka dapat ditarik kesimpulan sebagai berikut:

1. Tidak ada pengaruh termal terhadap kestabilan lereng tanpa perkuatan geotekstil, dikarenakan keterbatasan yang dimiliki software PLAXIS 2D yaitu tidak dapat memberikan efek perubahan sifat mekanik tanah akibat pengaruh termal.

2. Semakin tinggi suhu yang diberikan kepada lereng dengan perkuatan geotekstil, maka semakin rendah nilai kestabilan lerengnya, meskipun perubahan nilai kestabilan lereng yang terjadi tidak signifikan. Hal ini terjadi akibat menurunnya nilai kuat tarik geotekstil seiring bertambahnya suhu pada thermal boundary.

3. Parameter termal yang paling berpengaruh terhadap kestabilan lereng dengan perkuatan geotekstil adalah suhu dan ekspansi, karena nilai ekspansi tanah berpengaruh terhadap volumetrik tanah, semakin tinggi nilai ekspansi tanah, maka volume tanah semakin besar, oleh karena itu dengan meningkatnya volumetrik tanah, gesekan yang terjadi antara tanah dengan geotekstil semakin tinggi, sehingga kestabilan tanah dapat meningkat. Sedangkan kapasitas dan konduktivitas termal tidak berpengaruh terhadap nilai kestabilan lereng, karena kedua parameter tersebut hanya mempengaruhi sifat fisik tanah tanpa mempengaruhi sifat mekaniknya, sehingga kurang berpengaruh terhadap kekuatan tanah.

4. Pengaruh pemberian nilai ekspansi yang sama dengan nilai temperatur yang berbeda terhadap kestabilan lereng dengan perkuatan geotekstil yaitu adanya penurunan nilai $\boldsymbol{S} \boldsymbol{F}$ sebesar 1,2\% hingga 2,4\%, tergantung dari besaran temperatur yang diberikan. 


\section{DAFTAR RUJUKAN}

Agar, J., Morgenstern, R., \& Scott, J. (1986). Thermal Expansion and Pore Pressure Generation in Oil Sands. Canadian Geotechnical, 47(1), 31-37.

Badan Standarisasi Nasional. (2017). SNI-8640:2017. Tentang Persyaratan Perancangan Geoteknik. Jakarta: Badan Standarisasi Indonesia.

Bowles, J. E. (1984). Sifat-Sifat Fisis dan Geoteknis Tanah (Mekanika Tanah), Edisi Kedua. Jakarta: Erlangga.

Brinkgreve, R., Kumarswarny, S., \& Swolfs, W. (2016). PLAXIS 2D Manual. Netherlands: PLAXIS bv.

Das, B. M. (1991). Mekanika Tanah, Prinsip-Prinsip Rekayasa Geoteknis. Jilid I. Jakarta: Erlangga.

Ghuman, B., \& Lal, R. (1985). Thermal Conductivity, Thermal Diffusivity, and Thermal Capacity of Some Nigerian Soils. Soil Science, 139(1), 74-80.

Gonnet, Phillippe, \& Liang, Z. (2004). Thermal Conductivity and Coefficients of Thermal Expansion of SWNTS/Epoxy Nanocomposites. Florida: Florida State University.

Hamdhan, I. N., \& Clarke, B. G. (2010). Determination of Thermal Conductivity of Coarse and Fine Sand Soils. Proceedings World Geothermal Congress 2010 (pp. 1-2). Bali: Geothermal Energy.

Hardiyatmo, H. C. (2002). Mekanika Tanah I. Yogyakarta: Gadjah Mada University Press.

Jobmann, M., Poister, M., \& Schonebeck, M. (2007). Investigation on Thermal Expansion Effects in Clay Formations. Peine: DBE TECHNOLOGY.

Smith, G., \& Smith, I. G. (1998). Elements of Soil Mechanics th Edition. London: Wiley. 